\title{
ARTIFICIAL INTELLIGENCE AND VIRTUAL REALITY USE IN HEALTHCARE AND ORAL DISEASE PREVENTION
}

\author{
Jurgita Andruškienė, Evelina Daugẻlienė, Šarūnė Barsevičienė, Viktorija Venevičienė, \\ Arnas Murauskas, Irma Spiriajevienė \\ Klaipeda State University of Applied Sciences, Faculty of Health Sciences, \\ Department of Oral Care, Lithuania
}

Keywords: artificial intelligence, virtual reality, healthcare, oral disease prevention.

\begin{abstract}
Summary
Artificial intelligence and virtual reality tools are changing the healthcare experience for both patients and medical professionals. As the technology gets more affordable, it will be more and more widely adopted while more immersive technologies will come to the forefront. Methods - Analisis of scientific literature.

Results. There is a lack of mobile applications monitoring the periodontal status of patients and updating the dentist or the patient about dental health during the interval between visits. Virtual reality tools are being widely used for pain control in adult patients and children, as well as in surgery, rehabilitation, and psychiatry. Scientific study results have shown positive patient experiences towards the use of tele dentistry in oral health care. Considering the COVID-19 pandemic, healthcare providers should consider adapting patient pathways and using telehealth as a method of consultation in the recovery planning of services, as well as to reduce the spread of this highly transmissible disease. Increased self-efficacy and encouraged better individual dental hygiene is expected, because patients will be constantly reminded to take care of their oral health.

Conclusions. Technology innovations can potentially improve health behaviour and tooth brushing quality in children and adult persons and increase self-awareness in health. Innovative means need to be designed to achieve long-term, sustained improvements in health promotion. Future research should continue to evaluate mobile applications as part of intervention approaches to improve health behaviour and outcomes in vulnerable populations.
\end{abstract}

\section{Introduction}

Although the use of virtual reality (VR) in healthcare is not widespread yet, the technology holds great promise. Medical education, surgery, rehabilitation medicine, psychiatry, and psychology could all benefit from VR. Virtual reality can support better management of chronic pain, can treat fears and phobias, or help survive medical events, from as painful as childbirth until vaccination. VR is the common denominator of behavioral psychology, pain management, medical training, rehabilitation, and meditation (1-3).

The Apple Store and Google Play app store contain more than 318,000 medical apps, with hundreds of new apps added daily. E-Health (electronic health) is a broad term that describes the use of electronic devices to improve health. Mobile health (mHealth) is the part of eHealth that includes the use of mobile devices to gather data about an individual's health status and provides information to professionals and patients in real-time. There are many mHealth apps, such as those that monitor medical conditions like blood glucose levels (eg, SuCare, Sanofi-Aventis US LLC), blood pressure, and cholesterol (Medisana $\mathrm{GmbH}$ ) (eg, Vitadoc+, MedisanaGmbH). In an app for type 1 diabetes, patients can submit information and get management instructions in real-time (Roche Diabetes Care Inc.) (Gluci-Chek, Roche Diabetes Care Inc). There are also apps that provide exercise programs (eg, Runkeeper, ASICS), weight loss plans (Good Housekeeping) (eg, MyFitness Pal Calorie Counter and Diet Tracker, Under Armour Inc), and functions for family planning (eg., Glow, Glow Inc). Some apps can alert a patient to when they need further professional assistance. Other apps assist in the diagnosis of specific pathologies, such as an app that uses the image processing of urine tests to diagnose kidney disease (4) (Healthy.io). In dentistry, there are apps that show clinical procedures using 3D imagery (eg, Lexi- 
DENTAL COMPLETE, Lexicomp). However, following an extensive search, there is a lack of apps that monitor gingivitis. Now in 2020, there are no available m-Health apps that monitor the periodontal status of patients and update the dentist or the patient about dental health during the interval between visits. The oral cavity remains unmonitored, and without proper oral hygiene, gingivitis can progress and worsen (5). It' known, that poor oral health can affect someone's ability to eat, speak, smile and socialise normally, due to pain or social embarrassment (6). The study aimed to analyse apps developed for smartphones that promote tooth brushing amongst children using the Coventry, Aberdeen, and London-Refined (CALO-RE) taxonomy for behaviour change. Tooth brushing apps available in English and free to download that purported to assist with brushing were searched on the Apple app store using search terms based on Boolean logic and included AND combinations for keywords tooth brushing, children, toothbrush and motivation in the health and fitness category; six apps met the inclusion criteria and were downloaded. The behaviour change taxonomies were assessed individually for each app and scored as per coding and analysed for presence or absence. Only three of the behaviour change taxonomies were present in all apps, i.e. information provision (general), goal setting (behaviour) and prompt practice. Setting graded tasks, self-monitoring of behavioural outcome, demonstration of behaviour, prompt use of imagery and time management were included in four out of six apps. The use of mobile phone apps is a new arena for oral healthcare motivation and prevention in children (7).

Aim of the study - to analyze the use of artificial intelligence and virtual reality for health care and oral disease prevention using a research method of scientific literature analysis.

Methods - analisis of scientific literature.

\section{Results and discussion}

Virtual Reality Use in Healthcare. Perhaps the most successful application of VR so far is its utilization for stress release and pain reduction for patients suffering from chronic pain (8-9).

There are two distinct moments indicating VR is working: "the moment of cognitive immersion" and "the moment of physiologic immersion". The first refers to the first 20 seconds of using VR, when patients realize alone or with the help of the research staff that VR has a 360-degree extension and only if they move their head, are they able to explore the scene in its entirety. "The moment of physiologic immersion" comes after 3-5 minutes of using VR, after patients cognitively recognize that they are in a 3-D environment. After this realization happens in the brain, the next step is when the body also adjusts to the experience (10).

There is also a concern whether VR is for everyone or are there any conditions, when it is not recommended. The researcher reminded that VR may cause motion sickness in some users. So, they excluded patients with a history of motion sickness and vertigo, and anyone experiencing active nausea or vomiting (11).

Delivering difficult news being it about a cancer diagnosis or the death of the patient to the family requires enormous strength of mind and empathy from the doctor, but also appropriate practice. That is where VR comes into the picture (12).

Many people have a fear of needles, while plenty of others cannot get themselves diverted from the experienced pain, virtual reality can help overcome fear and reduce pain. Anxiety while in hospital, the constant worry about an upcoming procedure and the actual pain that one can suffer during or after a procedure are understandably taxing on anyone. VR is presenting itself as an enticing solution to help patients relax and suffer to a lesser extent in such situations. In a recent pilot study, patients undergoing surgery at St George's Hospital in London had the option to use a VR headset prior to and during their operation to view calming landscapes during the procedure. $100 \%$ of the participants reported that their overall hospital experience was improved by wearing the headset, while $94 \%$ said they felt more relaxed. Furthermore, $80 \%$ said they felt less pain after wearing the headset and $73 \%$ reported feeling less anxious (13).

Earlier studies with patients suffering from gastrointestinal, cardiac, neurological, and post-surgical pain have shown a decline in their pain levels when using VR to distract them from painful stimuli (14).

For patients who survived a stroke or traumatic brain injury, time is of the essence. The earlier they start rehabilitation, the better chances they have for successfully regaining lost functions. Bringing a gamified approach to physical therapy for such patients is Neuro Rehab VR. Collaborating with physicians and therapists, the company develops VR training exercises with machine learning to tailor each exercise to patients' therapeutic needs. The aim is to make physical therapy more enjoyable to increase patient engagement (15).

Such methods have been proven to be indeed effective. In a study published last November, researchers found that after VR therapy, children with cerebral palsy experienced a significant improvement in their mobility. The authors of this study further called for adding this method to conventional rehabilitation techniques to improve outcomes (16).

Above are only some of the many examples of how VR 
is changing the healthcare experience for both patients and medical professionals. As the technology gets more affordable, it will be more and more widely adopted while more immersive technologies will come to the forefront.

Mobile Application Use in Dental Care. Mobile health apps can help people manage their own health and wellness, promote healthy living and gain access to useful information when and where they need it. The Brush DJ oral health app was developed to use the opportunity mobile apps offer to motivate an evidence-based oral hygiene routine. Seventy percent of respondents reported that their teeth felt cleaner since using the app. Eighty-eight percent reported the app motivated them to brush their teeth for longer and 92.3\% would recommend the app to their friends and family (17).

A two-phase, sequential, embedded mixed methods design explored how the app influenced the attitudes, beliefs, perceived behavioural control, and intentions (theory of planned behaviour) of parents of pre-schoolers. Parents' behavioural intentions or oral health behaviours with their pre-schoolers did not significantly change from pre- to postintervention $(p>.05)$. Social norms and perceived behavioural control predicted behavioural intentions pre-intervention and behavioural change post-intervention. Thematic analysis revealed that parents' belief in the importance of establishing oral health habits and brushing reminders and videos delivered via a mobile application supported efforts to form oral health habits. The use of theory of planned behaviour constructs in the development of oral health promotions aimed at parents of pre-schoolers was partially supported. A dental smartphone app may aid parents to make good oral health habits part of their pre-schooler's daily routine (18).

Adolescents with fixed orthodontic appliances are at high risk of developing dental caries. To date, new smartphone technologies have seldom been used to support them in the preventive behaviour that can help prevent dental caries. After an intervention-mapping process, smartphone application (the WhiteTeeth app) for preventing dental caries through improved oral-health behaviour and oral hygiene, we developed. The app, which is intended to be used at home, will help adolescents with fixed orthodontic appliances perform their oral self-care behaviour. The app is based on the Health Action Process Approach theory and incorporates several behaviour-change techniques that target the psychosocial factors of oral-health behaviour. The protocol of a randomized controlled trial to evaluate the effects of the WhiteTeethapp on oral-health behaviour and oral-hygiene outcomes (presence of dental plaque and gingival bleeding) compared with those of care as usual, in patients aged 12-16 with fixed orthodontic appliances, was created. Since the intervention was designed to target psychosocial factors in the motiva- tional and volitional components of the behaviour-change process, it was hypothesized that the app will cause greater improvements in oral-health behaviour and oral hygiene more than traditional oral-health-promotion programs (i.e., care as usual) (19).

The study was aiming to evaluate the effectiveness of mobile applications and text messages, compared with conventional oral hygiene instructions, for improving oral health knowledge and/or reducing gingival inflammation, when delivered to adolescents, adults and mothers of young children. Randomized clinical trials evaluating the use of mobile applications or text messages related to oral hygiene and/ or oral health education were screened. Among the fifteen studies selected, twelve (80\%) used text messages and thirteen $(87 \%)$ showed better results when mobile technology was used. Mobile health strategy can be used as an adjunct component in managing gingivitis, acquiring oral health knowledge, and improving oral hygiene (6).

Oral self-care plays an important role in maintaining oral health and preventing the occurrence of oral diseases. The association between good oral care and good oral hygiene is well known. However, the adherence to a proper daily oral hygiene regimen generally remains poor, so the prevalence of oral diseases remains high. Periodontal disease is the most common oral disease in the population. To enhance the adherence to good oral hygiene behaviours for patients with periodontal disease, we developed a personalized and evidence-based mobile application as an intervention tool for the purpose of initiating and improving good oral self-care. The study aiming to demonstrate the systematic development process and content of the oral self-care mobile application, was performed. The systematic development process of oral self-care mobile application consisted of three phases: behavioural diagnosis, intervention design, and effectiveness assessment. Firstly, behavioural problem of oral self-care was identified by the experts in periodontics care. Secondly, the intervention functions and the mode of delivery were designed based on the capability-opportunity-motivation behavioural model, which is the underpinning model behind the behaviour change wheel framework. Thirdly, the developed app was evaluated by the experts through a heuristics evaluation checklist by adopting Morville's Honeycomb model, and the final version of oral self-care mobile application was assessed by the patients with periodontal disease using the System Usability Scale. The study presented a rigorous design process of developing an evidence-based and personalized mobile application for oral self-care. The results of the expert evaluation confirmed the validated design, and the participants were satisfied with the designed app (20).

Traditional dental care, which includes long-term oral 
hygiene maintenance and scheduled dental appointments, requires effective communication between dentists and patients. In this study, a new system was designed to provide a platform for direct communication between dentists and patients. A new mobile app, Dental Calendar, combined with cloud services specific for dental care was created by a team constituted by dentists, computer scientists, and service scientists. This new system would remind patients about every scheduled appointment and help them take pictures of their own oral cavity parts that require dental treatment and send them to dentists along with a symptom description. Dentists, by contrast, could confirm or change appointments easily and provide professional advice to their patients immediately. In the study, 26 dentists and 32 patients were evaluated by a questionnaire containing eight dental-service items before and after using this system. After using the Dental Calendar combined with cloud services, dentists were able to improve appointment arrangements significantly, taking care of the patients with sudden worse prosthesis $(\mathrm{p}<0.05)$. Patients also achieved significant improvement in appointment reminder systems, rearrangement of appointments in case of sudden worse prosthesis, and establishment of a direct relationship with dentists $(\mathrm{p}<0.05)$. Mobile app, Dental Calendar, in combination with cloud services, provided efficient service to both dentists and patients, and helped establish a better relationship between them. It also helped dentists to arrange appointments for patients with sudden worsening of prosthesis function (21).

Efforts to improve toothbrushing in children have focused on health education based on the premise that inadequate knowledge is the main barrier. However, findings from a recent systematic review indicate that health education alone does not significantly improve toothbrushing attitudes or behaviours (22). Most caregivers know toothbrushing is important but lack self-efficacy and other skills to enforce toothbrushing habits (23).

Most families own devices that give them access to mobile health games (24). Two systematic reviews reported limited support for mobile games (25-26) but the original interventions were found to be passive (e.g., text reminders, monitoring), making it likely that the problem was with weak intervention design. In terms of toothbrushing games, a U.K. study surveyed 189 toothbrushing mobile game users ages 7-75 years (e.g., how clean did your teeth feel after using the game) (27). Most users were adults, the game was not tailored to children, and the study focused on perceptions rather than behaviours. A second study described a proposed intervention for a toothbrushing game for Dutch teens (28). Dental researchers have explored online coaching, text messages, and "selfie" photographs as ways to improve toothbrushing, but none have been scaled commercially (29-31).

Mobile toothbrushing games for children have become ubiquitous despite the lack of evidence demonstrating effectiveness. The goal of this pilot study was to evaluate a commercially available mobile children's toothbrushing game called Brush Up and assess whether the game could potentially help improve toothbrushing behaviours. We tested the hypothesis that game play would be associated with improvements in toothbrushing quality. The purpose of the pilot study was to evaluate changes in toothbrushing behaviours associated with a mobile game app. Thirty-four five- to sixyear-olds were taught to use the Brush $\mathrm{Up}^{\mathrm{TM}}$ game app and played it once per day at home for seven days. The primary outcome was toothbrushing quality measured as duration and distribution. The paired $t$ test was used to assess pre/post changes and Holm's method adjusted for multiple testing ( $\alpha$ equals 0.05 ). The mean age was $73.7 \pm 6.6$ months; 29.4 percent were female, and 47.1 percent were Caucasian. After seven days, toothbrushing duration increased significantly $(\mathrm{p}<0.001)$. Toothbrushing distribution improved with increased brushing of the lingual, maxillary occlusal, and posterior buccal surfaces. For 15 children who played the game for 14 days, even greater improvements in quality and distribution were observed. Improvements in toothbrushing did not persist one year later without further app use but there were noted changes that could be clinically meaningful. Mobile health game apps can potentially improve toothbrushing quality in children. Additional trials are needed to assess mobile toothbrushing game apps (32).

Smartphone apps can be a valuable means for education and prevention to improve the health of children, adolescents, and adults. A recent review of apps has revealed that there are over 1,000 patient-focused oral hygiene apps available on the Apple App Store and Google Play (Android) store. The research aimed to objectively assess the quality of 20 commercially available, patient-focused oral hygiene apps using the Mobile App Rating Scale (MARS). Furthermore, the accuracy of oral hygiene-related information contained within the apps was assessed. Apps meeting inclusion criteria were evaluated for: 1) quality using the MARS tool; and 2) information accuracy using an eight-item, evidence-based checklist relating to important aspects in the prevention of caries and periodontal disease. The mean app quality score was 3.4/5 (2.3-4.9). On average, of the four MARS subscales assessed, 'functionality' had the highest mean score (4) and 'information' had the lowest (2.9). Regarding the accuracy of information contained within these apps, only two were found to contain accurate information for all eight items of the checklist. The majority $(60 \%)$ of the apps $(n=13)$ did 
not contain information relating to at least $50 \%$ or more of the items present. Currently available apps appear to be functional, however, there is a need to improve engagement, aesthetics and most importantly information content of apps.

Performing proper toothbrushing is a complicated process for children. Therefore, the aim of the study was to investigate the effect of a smartphone app for improving manual toothbrushing via a gravitation sensor. In this prospective, controlled, single-blinded, randomized clinical trial, 49 children (mean age $5.1 \pm 0.6$ years, 27 female) were randomly assigned to test $(n=26)$ and control $(n=23)$ groups. All children were provided with manual toothbrushes with an integrated gravitation sensor, and they received oral health instructions. Only the children of the test group got an additional smartphone app to visualize and reward proper brushing in form and time. At baseline and recalls after 6 and 12 weeks, plaque, and gingival indices (QHI, PBI) were recorded for analysis between the two groups. At baseline, there were no significant differences between the test and control group regarding plaque and gingival indices $(\mathrm{QHI}$ : $2.36 \pm 0.7$ and $2.42 \pm 0.8 ; p=0.94$; PBI: $0.42 \pm 0.2$ and 0.47 $\pm 0.3 ; \mathrm{p}=0.59$ ). At the 6 - and 12 -week recalls, the test group showed statistically -significantly better oral health indices than the controls (6-week recall, QHI: $0.8 \pm 0.5$ and $1.88 \pm$ $0.9 ; \mathrm{p}<0.001$; PBI: $0.08 \pm 0.1$ and $0.26 \pm 0.2 ; \mathrm{p}<0.001 ; 12-$ week recall, QHI: $0.44 \pm 0.5$ and $1.49 \pm 0.7 ; \mathrm{p}<0.001$; PBI: $0.05 \pm 0.18$ and $0.21 \pm 0.1 ; p<0.001)$. The results highlight the enormous possibilities of a toothbrushing application via the smartphone, at least for medium-term oral hygiene improvement in preschool children and even after excluding the app. The long-term effect should also be investigated to exclude the expected novelty effect (33).

The primary objective of this exploratory study was to evaluate the short-term (four months) impact of a tooth brushing learning programme based on pictograms generated by the çATED app for iPad designed for patients with autistic spectrum disorder. Fifty-two ASD patients, between the ages of 3 and 19 years, from seven educational centres, were included. A tooth brushing training programme was proposed in collaboration with the educational teams. Observation grids were used to evaluate autonomy during tooth brushing and interaction with the iPad. The results showed improvement of tooth brushing. The children progressively acquired the various brushing skills, although some steps remained difficult to perform. Interactions with the iPad also improved during the programme, encouraging the use of this tool in learning of tooth brushing. Daily assistance of the children improved the efficacy of tooth brushing, contributing to the preventive care of these patients. The use of an iPad in oral hygiene, especially for learning of tooth brushing, is simple and effective (34). Objective of the study was to investigate the effect of using mobile applications active reminders to improve oral hygiene in comparison to verbal oral hygiene instructions. Two-arm parallel randomised controlled trial was performed. Forty-four 12-year-old and older patients participated in the study. Subjects undergoing orthodontic treatment with fixed appliances were randomly assigned to one of two groups using simple randomisation. Group I: subjects received a mobile application that sends active reminders of oral hygiene three times a day $(n=22)$. Group II: subjects received verbal oral hygiene instructions verbally during their routine orthodontic visits $(n=22)$. Two primary outcomes were assessed using plaque index (PI) and gingival index (GI) for Ramfjord teeth to evaluate the level of oral hygiene at baseline and after 4 weeks. Mean differences for PI and GI for group I were reduced from T1 to $\mathrm{T} 2(\mathrm{P}<0.05, \mathrm{P}<0.05)$ but did not significantly change for group II $(\mathrm{P}>0.05, \mathrm{P}>0.05)$. Both PI and GI significantly reduced for group I compared to group II between $\mathrm{T} 1$ and T2 $(\mathrm{P}<0.05, \mathrm{P}<0.05)$. PI and GI all significantly decreased after 4 weeks of using active reminders of oral hygiene instructions on mobile application compared to verbal oral hygiene instructions (35).

MET technology and Teledentistry approach in the modern patient education. Novel electric toothbrushing monitoring system called MET that tracks brushing coverage for all the 15 surfaces of teeth and detects different types of incorrect brushing techniques was presented. This design is inspired by observation that the motor inside an electric toothbrush generates a unique magnetic field, which can serve as a reliable signal for position and orientation tracking. MET is the first system that tracks both the position and orientation of an unmodified electric motor using magnetic inductive sensing. Experiments with fourteen users show that the average toothbrushing surface recognition accuracy of MET is $85.3 \%$. Moreover, MET is robust to user location changes and posture variations and does not require any training from the users. Experimental results also demonstrate our significant advantages over existing commercial systems (36).

Scientific study results have shown positive patient experiences towards the use of tele dentistry in oral health care. Considering COVID-19 pandemic, healthcare providers should consider adapting patient pathways and using telehealth as a method of consultation in the recovery planning of services, as well as to reduce the spread of this highly transmissible disease (37).

More than $70 \%$ of Saudi Arabian dental professionals agreed or strongly agreed that tele dentistry would improve dental practice through enhancing communication with pe- 
ers, guidance, and referral of new patients. A substantial proportion of respondents (60-70\%) expressed uncertainty with technical reliability, privacy, and diagnostic accuracy. The participants' qualification was statistically significant with usefulness of tele dentistry for patients $(p=0.027)$, while work experience in years was statistically significant with both usefulness of tele dentistry for dental practice and patients ( $p=0.046$ and $<0.0001$ respectively). Tele dentistry is believed to improve dental care provided to patients and time management efficiency. In addition, tele dentistry can be a useful tool for peer education, consultations and ensures proper channelling for referrals (38).

Expected benefits for health of users of mobile application and science development. Mobile health app offers an opportunity to improve dental services, because it is designed for remote patient self-monitoring but still ensure dental hygienist-patient communication. This oral health management app supports individuals in monitoring their own oral health conditions. Expected benefits for oral health of users of mobile application include motivation enhancement. The most frequently reported theme by oral health apps users was that the app motivated various aspects of the user's oral hygiene routine. Respondents reported that the app motivated them to brush their teeth, to brush for longer, that they no longer found the process boring $(27,39)$.

With mobile technology advancements, mobile health apps can close communication gap by offering variable tools to keep the channels of communication between patients and dental hygienists open. Medical applications make smartphones useful tools in the practice of evidence-based medicine at the point of care, in addition to their use in mobile clinical communication. Also, smartphones can play a very important role in patient education, disease self-management, and remote monitoring of patients (40).

Increased self-efficacy and encouraged better individual dental hygiene is expected, because patients will be constantly reminded to take care of their oral health. Evidence of the daily oral hygiene tasks needed to be carried out to maintain good oral health is known (41), but there is also an evidence that a significant percentage of the population do not accomplish these daily tasks, with females brushing their teeth significantly more often than males (42). In a 2015 study the use of a mobile app to motivate evidence-based oral hygiene behavior seventy percent $(n=113)$ of respondents reported that their teeth felt cleaner since using the app. Eighty-eight percent $(n=133)$ reported the app motivated them to brush their teeth for longer (27).

Patients using mobile dental hygienist app are expected to know what good oral health is and its association with dental plaque, acknowledge the risk of not brushing teeth as recommended and its consequences, know the benefits of maintaining good oral health, know how to brush teeth, feel able to prevent dental diseases and gain confidence in ability to brush teeth twice daily, develop tooth brushing skills to remove all dental plaque and be able to self - check their oral health status. A survey carried out among patients in 2012 found $59 \%$ of respondents indicated that mobile health apps would change the way health information is sought (43).

\section{Conclusions}

Technology innovations can potentially improve health behavior and tooth brushing quality in children and adult persons and increase self-awareness in health. Innovative means need to be designed to achieve long-term, sustained improvements in health promotion. Future research should continue to evaluate mobile applications as part of intervention approaches to improve health behaviour and outcomes in vulnerable populations.

\section{References}

1. Arane K, Behboudi A, Goldman RD. Virtual reality for pain and anxiety management in children. Can Fam Physician 2017;63(12):932-934.

2. Ahmad M, Bani Mohammad E, Anshasi HA. Virtual Reality Technology for Pain and Anxiety Management among Patients with Cancer: A Systematic Review. Pain Manag Nurs 2020;21(6):601-607.

https://doi.org/10.1016/j.pmn.2020.04.002

3. Eijlers R, Utens EMWJ, Staals LM, de Nijs PFA, Berghmans JM, Wijnen RMH, Hillegers MHJ, Dierckx B, Legerstee JS. Systematic Review and Meta-analysis of Virtual Reality in Pediatrics: Effects on Pain and Anxiety. Anesth Analg 2019;129(5):1344-1353.

https://doi.org/10.1213/ANE.0000000000004165

4. Leddy J, Green JA, Yule C, Molecavage J, Coresh J, Chang AR. Improving proteinuria screening with mailed smartphone urinalysis testing in previously unscreened patients with hypertension: a randomized controlled trial. BMC Nephrol 2019;20(1):132.

https://doi.org/10.1186/s12882-019-1324-Z

5. Zotti F, Dalessandri D, Salgarello S, Piancino M, Bonetti S, Visconti L, Paganelli C. Usefulness of an app in improving oral hygiene compliance in adolescent orthodontic patients. Angle Orthod 2016;86(1):101-107.

https://doi.org/10.2319/010915-19.1

6. Toniazzo MP, Nodari D, Muniz FWMG, Weidlich P. Effect of mHealth in improving oral hygiene: A systematic review with meta-analysis. J Clin Periodontol 2019;46(3):297-309.

https://doi.org/10.1111/jcpe.13083

7. Hotwani K, Sharma K, Nagpal D, Lamba G, Chaudhari P. Smartphones and tooth brushing: content analysis of the current 
available mobile health apps for motivation and training. Eur Arch Paediatr Dent 2020;21(1):103-108.

https://doi.org/10.1007/s40368-019-00457-1

8. Jones T, Moore T, Choo J. The Impact of Virtual Reality on Chronic Pain. PLoS One 2016;11(12):e0167523. https://doi.org/10.1371/journal.pone.0167523

9. Mallari B, Spaeth EK, Goh H, Boyd BS. Virtual reality as an analgesic for acute and chronic pain in adults: a systematic review and meta-analysis. J Pain Res 2019;12:2053-2085. https://doi.org/10.2147/JPR.S200498

10. Blum J, Rockstroh C, Göritz AS. Heart Rate Variability Biofeedback Based on Slow-Paced Breathing With Immersive Virtual Reality Nature Scenery. Front Psychol 2019;10:2172. https://doi.org/10.3389/fpsyg.2019.02172

11. Koch A, Cascorbi I, Westhofen M, Dafotakis M, Klapa S, Kuhtz-Buschbeck JP. The Neurophysiology and Treatment of Motion Sickness. Dtsch Arztebl Int 2018;115(41):687-696. https://doi.org/10.3238/arztebl.2018.0687

12. Guetterman TC, Sakakibara R, Baireddy S, Kron FW, Scerbo MW, Cleary JF, Fetters MD. Medical Students' Experiences and Outcomes Using a Virtual Human Simulation to Improve Communication Skills: Mixed Methods Study. J Med Internet Res 2019;21(11):e15459.

https://doi.org/10.2196/15459

13. Walther-Larsen S, Petersen T, Friis SM, Aagaard G, Drivenes B, Opstrup P. Immersive Virtual Reality for Pediatric Procedural Pain: A Randomized Clinical Trial. Hosp Pediatr 2019;9(7):501-507.

https://doi.org/10.1542/hpeds.2018-0249

14. Glennon C, McElroy SF, Connelly LM, Mische Lawson L, Bretches AM, Gard AR, Newcomer LR. Use of Virtual Reality to Distract From Pain and Anxiety. Oncol Nurs Forum 2018;45(4):545-552.

https://doi.org/10.1188/18.ONF.545-552

15. Pallavicini F, Pepe A. Virtual Reality Games and the Role of Body Involvement in Enhancing Positive Emotions and Decreasing Anxiety: Within-Subjects Pilot Study. JMIR Serious Games 2020;8(2):e15635.

https://doi.org/10.2196/15635

16. Prasertsakul T, Kaimuk P, Chinjenpradit W, Limroongreungrat W, Charoensuk W. The effect of virtual reality-based balance training on motor learning and postural control in healthy adults: a randomized preliminary study. Biomed Eng Online 2018;17(1):124.

https://doi.org/10.1186/s12938-018-0550-0

17. Underwood B, Birdsall J, Kay E. The use of a mobile app to motivate evidence-based oral hygiene behaviour. Br Dent J 2015;219(4):E2.

https://doi.org/10.1038/sj.bdj.2015.660

18. Lozoya CJS, Giblin-Scanlon L, Boyd LD, Nolen S, Vineyard J. Influence of a Smartphone Application on the Oral Health
Practices and Behaviors of Parents of Preschool Children. J Dent Hyg 2019;93(5):6-14.

19. Scheerman JFM, van Meijel B, van Empelen P, et al. Study protocol of a randomized controlled trial to test the effect of a smartphone application on oral-healthbehavior and oral hygiene in adolescents with fixed orthodontic appliances. BMC Oral Health 2018;18(1):19.

https://doi.org/10.1186/s12903-018-0475-9

20. Chang WJ, Lo SY, Kuo CL, Wang YL, Hsiao HC. Development of an intervention tool for precision oral self-care: Personalized and evidence-based practice for patients with periodontal disease. PLoS One. 2019;14(11):e0225453.

https://doi.org/10.1371/journal.pone.0225453

21. Lin CY, Peng KL, Chen J, et al. Improvements in dental care using a new mobile app with cloud services. J Formos Med Assoc 2014;113(10):742-749.

https://doi.org/10.1016/j.jfma.2014.02.009

22. Werner H, Hakeberg M, Dahlström L, Eriksson M, Sjögren P, Strandell A, Svanberg T, Svensson L, Wide Boman U. Psychological interventions for poor oral health: A systematic review. J Dent Res 2016;95(5):506-514.

https://doi.org/10.1177/0022034516628506

23. Huebner CE, Riedy CA. Behavioral determinants of brushing young children's teeth: implications for anticipatory guidance. Pediatr Dent 2010;32(1):48-55.

24. Smith A. U.S. smartphone use in 2015. Pew Research Center 2015. http://www.pewinternet.org/2015/04/01/us-smartphoneuse-in-2015/.

25. Sheehy S, Cohen G, Owen KR. Self-management of diabetes in children and young adults using technology and smartphone applications. Curr Diabetes Rev 2014;10(5):298-301.

https://doi.org/10.2174/1573399810666141010113050

26. Quelly SB, Norris AE, DiPietro JL. Impact of mobile apps to combat obesity in children and adolescents: A systematic literature review. J Spec PediatrNurs 2016;21(1):5-17.

https://doi.org/10.1111/jspn.12134

27. Underwood B, Birdsall J, Kay E. The use of a mobile app to motivate evidence-based oral hygiene behaviour. Br Dent J 2015;219(4):E2.

https://doi.org/10.1038/sj.bdj.2015.660

28. Scheerman JFM, van Meijel B, van Empelen P, Kramer GJC, Verrips GHW, Pakpour AH, Van den Braak MCT, van Loveren C. Study protocol of a randomized controlled trial to test the effect of a smartphone application on oral-healthbehavior and oral hygiene in adolescents with fixed orthodontic appliances. BMC Oral Health 2018;18(1):19. https://doi.org/10.1186/s12903-018-0475-9

29. Hurling R, Claessen JP, Nicholson J, Schäfer F, Tomlin CC, Lowe CF. Automated coaching to help parents increase their children's brushing frequency: an exploratory trial. Community Dent Health 2013;30(2):88-93.

30. Schluter P, Lee M, Hamilton G, Coe G, Messer-Perkins H, Smith 
B. Keep on brushing: a longitudinal study of motivational text messaging in young adults aged 18-24 years receiving Work and Income Support. J Public Health Dent 2015;75(2):118-125. https://doi.org/10.1111/jphd.12079

31. Kumar PD, Mohandoss AA, Walls T, Rooban T, Vernon LT. Using smartphone video "selfies" to monitor change in toothbrushing behavior after a brief intervention: A pilot study. Indian J Dent Res 2016;27(3):268-277.

https://doi.org/10.4103/0970-9290.186241

32. Jacobson D, Jacobson J, Leong T, Lourenco S, Mancl L, Chi DL. Evaluating Child Toothbrushing Behavior Changes Associated with a Mobile Game App: A Single Arm Pre/Post Pilot Study. Pediatr Dent 2019;41(4):299-303.

33. Alkizy M, Midani R, Höfer M, Splieth C. Improving Toothbrushing with a Smartphone App: Results of a Randomized Controlled Trial. Caries Res 2019;53(6):628-635.

https://doi.org/10.1159/000499868

34. Lefer G, Bourdon P, Mercier C, Lopez-Cazaux S. Apprentissage du brossagedentaire chez des enfants présentant un trouble du spectre autistique :effets de l'utilisation de tablettestactiles [Teaching tooth brushing to children with autistic spectrum disorder : A tablet-based training programme.]. SantePublique 2018;30(3):297-306

https://doi.org/10.3917/spub.183.0297

35. Alkadhi OH, Zahid MN, Almanea RS, Althaqeb HK, Alharbi TH, Ajwa NM. The effect of using mobile applications for improving oral hygiene in patients with orthodontic fixed appliances: a randomised controlled trial. J Orthod 2017;44(3):157-163.

https://doi.org/10.1080/14653125.2017.1346746

36. Hua Huang, Shan Lin. MET: a magneto-inductive sensing based electric toothbrushing monitoring system. In The 26th Annual International Conference on Mobile Computing and Networking (MobiCom '20) 2020;19:1-14.

https://doi.org/10.1145/3372224.3380896

37. Rahman N, Nathwani S, Kandish T. Teledentistry from a patient perspective during the coronavirus pandemic. Br Dent $\mathrm{J}$ 2020;14:1-4.

https://doi.org/10.1038/s41415-020-1919-6

38. Al-Khalifa KS, AlSheikh R. Teledentistry awareness among dental professionals in Saudi Arabia. PLoS One 2020;15(10):e0240825.

https://doi.org/10.1371/journal.pone.0240825

39. Kaczmarczyk KH, Gray-Burrows KA, Vinall-Collier K, Day PF. Oral health promotion apps: an assessment of message and behaviour change potential. Int J Qual Health Care 2021;33(1):mzaa112.

https://doi.org/10.1093/intqhe/mzaa112

40. Mosa AS, Yoo I, Sheets L. A systematic review of healthcare applications for smartphones. BMC Med Inform Decis Mak 2012;12:67.

https://doi.org/10.1186/1472-6947-12-67
41. Public Health England. Delivering better oral health: an evidence based toolkit for prevention. 2014. https:/www.gov. uk/government/uploads/system/uploads/attachment_data/ file/367563/DBOHv32014OCTMainDocument_3.pdf.

42. Mamai-Homata E, Koletsi-Kounari H, Margaritis V. Gender differences in oral health status and behavior of Greek dental students: A meta-analysis of 1981, 2000, and 2010 data. Journal of International Society of Preventive Community Dentistry 2016; 6(1):60-68.

https://doi.org/10.4103/2231-0762.175411

43. PwC Emerging mHealth: paths for growth. 2014. https://www. pwc.com/gx/en/healthcare/mhealth/assets/pwc-emergingmhealth-full.pdf.

\section{DIRBTINIS INTELEKTAS IR VIRTUALIOS REALYBESS PANAUDOJIMAS SVEIKATOS PRIEŽIŪROS IR BURNOS LIGŲ PREVENCIJAI}

J. Andruškienė, E. Daugèlienė, Š. Barsevičienė,

V. Venevičienė, A. Murauskas, I. Spiriajevienè

Raktažodžiai: dirbtinis intelektas, virtuali realybė, sveikatos priežiūra, burnos ligų prevencija.

Santrauka

Dirbtinis intelektas ir virtualios realybės priemonès keičia sveikatos priežiūros patirti tiek pacientams, tiek medicinos specialistams. Kai technologijos tampa labiau prieinamos, jos bus vis plačiau pritaikytos, tuo tarpu dar pažangesnès technologijos pasirodys ateityje. Metodas - mokslinių straipsnių analizè.

Rezultatai. Trūksta mobiliujų programų stebėti pacientų periodonto būklę, susisiekti odontologui ir pacientui dantų sveikatos klausimais tarp paciento vizitų pas odontologą. Virtualios realybès priemonès plačiai naudojamos suaugusiųjų ir vaikų skausmo kontrolei, taip pat chirurgijoje, reabilitacijoje ir psichiatrijoje. Mokslinių tyrimų rezultatai parode teigiamą pacientų patirtị, taikant nuotolinę odontologiją burnos sveikatos priežiūrai. Atsižvelgdami ị COVID-19 pandemiją, sveikatos priežiūros paslaugų teikejjai turètų apsvarstyti galimybę atliepti pacientų poreikius naudojant telehealth technologijas kaip konsultavimo metodą, planuojant paslaugų atkūrimą, mažinant šios užkrečiamosios ligos plitimą. Tikimasi padidinti saviveiksmingumą ir skatinti geresnę individualią dantų higieną, nes pacientams bus nuolat primenama rūpintis savo burnos sveikata.

Išvados. Technologijų naujovès gali pagerinti vaikų ir suaugusiųjų sveikatos raštingumą ir dantų valymo ypatumus bei padidinti savimonę sveikatos srityje. Norint pasiekti ilgalaikị sveikatos stiprinimo būdą, reikia sukurti novatoriškas priemones. Ateityje atliekant mokslinius tyrimus turètų būti toliau vertinamos mobiliosios programos kaip intervencinių metodų dalis, siekiant sveikatos srityje pagerinti gyventojų elgesi ir rezultatus.

Adresas susirašinèti: i.spiriajeviene@kvk.lt

Gauta 2021-07-04 